\title{
A Fast, Highly Efficient, and Green Protocol for Synthesis of Biscoumarins Catalyzed by Silica Sulfuric Acid Nanoparticles as a Reusable Catalyst
}

\author{
Bahareh Sadeghi and Tayebe Ziya \\ Department of Chemistry, Yazd Branch, Islamic Azad University, P.O. Box 89195-155, Yazd 8916871967, Iran \\ Correspondence should be addressed to Bahareh Sadeghi; bsadeghia@gmail.com
}

Received 13 May 2013; Accepted 11 July 2013

Academic Editor: Christophe Len

Copyright (C) 2013 B. Sadeghi and T. Ziya. This is an open access article distributed under the Creative Commons Attribution License, which permits unrestricted use, distribution, and reproduction in any medium, provided the original work is properly cited.

Silica sulfuric acid nanoparticles have been prepared and shown to efficiently catalyse the reaction between an aromatic aldehyde or phenylglyoxal and a 4-hydroxycoumarin at reflux in $\mathrm{EtOH}$ to afford the biscoumarin derivatives in high yield.

\section{Introduction}

A variety of biological activities are associated with coumarins and biscoumarins, for example, anticoagulants and antianthelmintic and antifungal activities [1-3]. Furthermore, these compounds can be complexed with rare earth metals as anti-HIV agents [4]. The synthesis of biscoumarins has been reported in the presence of piperidine [5], molecular iodine [6], tetrabutylammonium bromide [7], [bmim] $\mathrm{BF}_{4}$ [8], sodium dodecyl sulfate [9], $\mathrm{SO}_{3} \mathrm{H}$-functionalized ionic liquid [10], and $\left[\mathrm{MIM}\left(\mathrm{CH}_{2}\right)_{4} \mathrm{SO}_{3} \mathrm{H}\right]\left[\mathrm{HSO}_{4}\right][11]$.

In this paper, we report a simple and efficient method for synthesis of biscoumarin derivatives using different aromatic aldehydes and phenylglyoxals and 4-hydroxycoumarin in the presence of silica sulfuric acid nanoparticles under reflux in ethanol. The catalyst is recyclable with reproducible results without any loss of its activity. The morphology of the silica sulfuric acid nanoparticles was observed using a scanning electron microscope (SEM).

\section{Experimental}

2.1. General. IR spectra were recorded on a Shimadzu IR-470 spectrometer in $\mathrm{KBr}$ discs. The NMR spectra were obtained on a Bruker Avance DRX-500 FT spectrometer $\left({ }^{1} \mathrm{H}\right.$ NMR at $500 \mathrm{~Hz},{ }^{13} \mathrm{C} \mathrm{NMR}$ at $125 \mathrm{~Hz}$ ) using $\mathrm{CDCl}_{3}$ as solvent with TMS as internal standard. Melting points were determined with an Electrothermal 9100 apparatus. Elemental analyses were performed using a Costech ECS 4010 CHNS-O analyzer at Analytical Laboratory of Science and Researches Unit of Islamic Azad University. The morphology of the catalyst was observed using an SEM model VEGA//TESCAN with an accelerating voltage of $15 \mathrm{kV}$. The chemicals used in this work were purchased from Sigma Aldrich and Fluka (Buchs, Switzerland) and were used without further purification.

2.2. Synthesis of Silica Sulfuric Acid Nanoparticles. The reagent was prepared by combination of chlorosulfonic acid (23.3 g) drop by drop over $10 \mathrm{~min}$ via a syringe to nanosilica gel powder $(60 \mathrm{~g})$ in a $100 \mathrm{~mL}$ flask at $0^{\circ} \mathrm{C}$. The reaction mixture was then stirred, and then after $30 \mathrm{~min}$, the white powder was separated. The dimensions of nanoparticles were observed with SEM (Figure 1). The size of particles is between 28 and $32 \mathrm{~nm}$.

2.3. General Procedure for the Synthesis of Biscoumarin. A mixture of 4-hydroxycoumarin $(2 \mathrm{mmol})$, aromatic aldehyde or arylglyoxal $(1 \mathrm{mmol}), \mathrm{SiO}_{2}-\mathrm{OSO}_{3} \mathrm{H}$ NPs $(0.003 \mathrm{~g})$, and EtOH $(5 \mathrm{~mL})$ was placed in a round bottom flask. The materials were mixed and refluxed for $20 \mathrm{~min}$. The progress of the reaction was followed by TLC ( $n$-hexane:ethylacetate). After completion of the reaction, the mixture was filtered to remove the catalyst. By evaporation of the solvent, the crude 


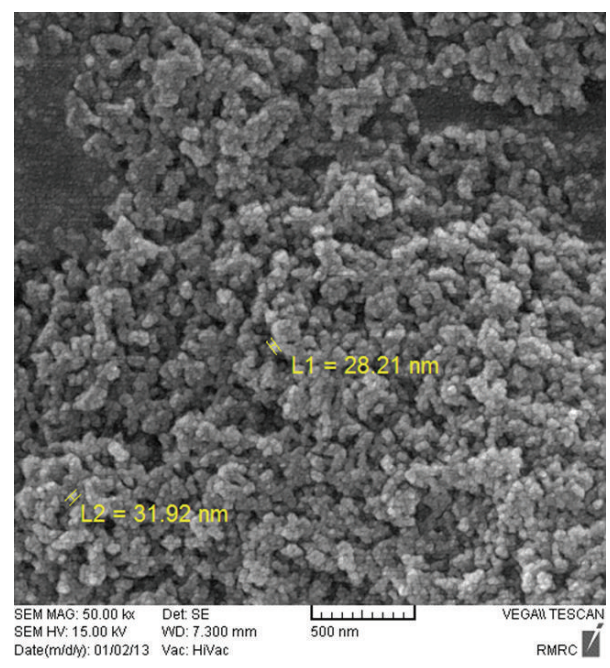

Figure 1: The SEM images of $\mathrm{SiO}_{2}-\mathrm{OSO}_{3} \mathrm{H}$ NPs.

product was recrystallized from hot ethanol to obtain the pure compound.

\subsection{Selected Spectral Data}

3,3'-Bis (4-hydroxy coumarin-3yl) (3-nitro-4-chlorophenyl) methane (4m). IR (KBr) $v_{\max }: 3450,3015,1664,1603,1561$, $1348,761 \mathrm{~cm}^{-1} .{ }^{1} \mathrm{H}$ NMR $\left(500 \mathrm{MHz}, \mathrm{CDCl}_{3}\right): \delta 6.3(s, 1 \mathrm{H}$, $\mathrm{CH}), 7.27(d, 2 \mathrm{H}, J=7.5 \mathrm{~Hz}$, aromatic), $7.34(d, 2 \mathrm{H}, J=$ $8.2 \mathrm{~Hz}$, aromatic), $7.48(d, 1 \mathrm{H}, J=8.2 \mathrm{~Hz}$, aromatic), 7.55$7.59(\mathrm{~m}, 3 \mathrm{H}$, aromatic), $7.79(s, 1 \mathrm{H}$, aromatic), $7.88(d, 2 \mathrm{H}$, $J=7.7 \mathrm{~Hz}$, aromatic), 12.3 (broad $s, 2 \mathrm{H}, \mathrm{OH}) \mathrm{ppm} .{ }^{13} \mathrm{C} \mathrm{NMR}$ $\left(125 \mathrm{MHz}, \mathrm{CDCl}_{3}\right): \delta 36.9,104.1,116.8,118.9,122.6,124.6,131.7$, 132.7, 133.3, 143.4, 148.5, 153.2, 165.2, 166.6 ppm. Anal. Calcd. For $\mathrm{C}_{25} \mathrm{H}_{14} \mathrm{ClNO}_{8}$ : C, 61.03; H, 2.83; N, 2.83 Found: C, 61.02; $\mathrm{H}, 2.87$; N, 2.85 .

3,3'-Bis (4-hydroxy coumarin-3yl) (2,4-dichlorophenyl) methane $(4 \mathrm{n})$. IR (KBr) $v_{\max }: 3485,3085,1664,1603,766 \mathrm{~cm}^{-1}$. ${ }^{1} \mathrm{H}$ NMR $\left(500 \mathrm{MHz}, \mathrm{CDCl}_{3}\right): \delta 6.1(s, 1 \mathrm{H}, \mathrm{CH}), 7.26(t d, 2 \mathrm{H}$, $J=8.5 \mathrm{~Hz}, J=2 \mathrm{~Hz}$, aromatic $), 7.39(t d, 2 \mathrm{H}, J=6.1 \mathrm{~Hz}$, $J=2 \mathrm{~Hz}$, aromatic), $7.41(d, 2 \mathrm{H}, J=8 \mathrm{~Hz}$, aromatic), 7.43 $(s, 1 \mathrm{H}$, aromatic), $7.66(t d, 2 \mathrm{H}, J=8.5 \mathrm{~Hz}, J=1.3 \mathrm{~Hz}$, aromatic), $8.05(d, 2 \mathrm{H}, J=6.4 \mathrm{~Hz}$, aromatic), 11.68 (broad $s, 2 \mathrm{H}, \mathrm{OH}) \mathrm{ppm} .{ }^{13} \mathrm{C} \mathrm{NMR}\left(125 \mathrm{MHz}, \mathrm{CDCl}_{3}\right): \delta 31.9,102.1$, $114.2,119.1,121.4,123.7,130.3,132.9,133.3,135.8,143.5,152.1$, 165.9, 167.1 ppm. Anal. Calcd. For $\mathrm{C}_{25} \mathrm{H}_{14} \mathrm{Cl}_{2} \mathrm{O}_{6}: \mathrm{C}, 62.38 ; \mathrm{H}$, 2.93 Found: C, 62.32; H, 2.79 .

3,3'-Bis (4-hydroxy coumarin-3yl) (4-nitrophenyl) ethanon (5a). IR (KBr) $v_{\max }: 3355,3015,1696,1664,1547,1357$, $754 \mathrm{~cm}^{-1} .{ }^{1} \mathrm{H}$ NMR $\left(500 \mathrm{MHz}, \mathrm{CDCl}_{3}\right): \delta 6.4(s, 1 \mathrm{H}, \mathrm{CH})$, $7.34(t d, 2 \mathrm{H}, J=7.4 \mathrm{~Hz}, J=2 \mathrm{~Hz}$, aromatic $), 7.36(m, 2 \mathrm{H}$, aromatic), 7.58 (dd, $2 \mathrm{H}, J=7.4 \mathrm{~Hz}, J=2 \mathrm{~Hz}$, aromatic), 7.78 ( $m, 2 \mathrm{H}$, aromatic), $7.91(d, 2 \mathrm{H}, J=8 \mathrm{~Hz}$, aromatic), $8.29(d$, $2 \mathrm{H}, J=8 \mathrm{~Hz}$, aromatic), 11.3 (broad $s, 2 \mathrm{H}, \mathrm{OH}) \mathrm{ppm} .{ }^{13} \mathrm{C}$ $\operatorname{NMR}\left(125 \mathrm{MHz}, \mathrm{CDCl}_{3}\right): \delta 80.2,104.1,115.7,119.2,121.7,124.2$,
128.4 , 130.2, 132.9, 142.1, 153.7, 158.2, 162.9, 167.2, 198.0 ppm. Anal. Calcd. For $\mathrm{C}_{26} \mathrm{H}_{15} \mathrm{NO}_{9}$ : C, 64.33; H, 3.11; N, 2.88 Found: C, 64.21; H, 3.04; N, 2.85 .

3,3'-Bis (4-hydroxy coumarin-3yl) (4-bromophenyl) ethanon (5b). IR (KBr) $v_{\max }: 3335,3085,1696,1648,759 \mathrm{~cm}^{-1} \cdot{ }^{1} \mathrm{H}$ $\operatorname{NMR}\left(500 \mathrm{MHz}, \mathrm{CDCl}_{3}\right): \delta 6.31(s, 1 \mathrm{H}, \mathrm{CH}), 7.24(d, 2 \mathrm{H}$, $J=7.5 \mathrm{~Hz}$, aromatic), $7.27(d, 2 \mathrm{H}, J=8.3 \mathrm{~Hz}$, aromatic), $7.5(t, 2 \mathrm{H}, J=7 \mathrm{~Hz}$, aromatic $), 7.58(d, 2 \mathrm{H}, J=8.5 \mathrm{~Hz}$, aromatic), $7.71(d, 2 \mathrm{H}, J=8.5 \mathrm{~Hz}$, aromatic), $7.84(d, 2 \mathrm{H}$, $J=7.5 \mathrm{~Hz}$, aromatic), 10.41 (broad $s, 2 \mathrm{H}, \mathrm{OH}) \mathrm{ppm} .{ }^{13} \mathrm{C} \mathrm{NMR}$ $\left(125 \mathrm{MHz} \mathrm{CDCl}_{3}\right): \delta 80.0,102.5,116.7,119.0,121.6,124.2,124.7$, $130.2,132.0,132.4,153.1,164.3,167.2,165.2,196.5$ ppm. Anal. Calcd. For $\mathrm{C}_{26} \mathrm{H}_{15} \mathrm{BrO}_{7}$ : C, 60.13; H, 2.91 Found: C, 60.08; H, 2.89 .

3,3'-Bis (4-hydroxy coumarin-3yl) (phenyl) ethanon (5c). IR $(\mathrm{KBr}) v_{\max }: 3405,3015,1692,1637,764 \mathrm{~cm}^{-1} .{ }^{1} \mathrm{H}$ NMR $\left(500 \mathrm{MHz}, \mathrm{CDCl}_{3}\right): \delta 6.35(s, 1 \mathrm{H}, \mathrm{CH}), 7.29(t d, 2 \mathrm{H}, J=$ $7.4 \mathrm{~Hz}, J=2 \mathrm{~Hz}$, aromatic), $7.35(m, 3 \mathrm{H}$, aromatic), $7.47(d$, $2 \mathrm{H}, J=7.8 \mathrm{~Hz}$, aromatic), $7.57(m, 2 \mathrm{H}$, aromatic), $7.71(m$, $2 \mathrm{H}$, aromatic), $7.82(d, 2 \mathrm{H}, J=8 \mathrm{~Hz}$, aromatic), 10.41 (broad $s, 2 \mathrm{H}, \mathrm{OH}) \mathrm{ppm} .{ }^{13} \mathrm{C} \mathrm{NMR}\left(125 \mathrm{MHz}, \mathrm{CDCl}_{3}\right): \delta 80.3,101.9$, $115.5,118.7,121.0,124.3,129.7,130.1,131.8,133.2,136.2,151.3$, 161.8, 167.4, 194.2 ppm. Anal. Calcd. For $\mathrm{C}_{26} \mathrm{H}_{16} \mathrm{O}_{7}$ : C, 70.9; H, 3.66 Found: C, 70.7; H, 3.59.

\section{Results and Discussion}

In continuation of our investigations of the application of solid acids in organic synthesis [12-16], we have investigated the synthesis of biscoumarin derivatives by condensation of a 4-hydroxycoumarin $\mathbf{1}$ and an aromatic aldehyde $\mathbf{2}$ or phenylglyoxals 3 in the presence of $0.003 \mathrm{~g} \mathrm{SiO}_{2}-\mathrm{OSO}_{3} \mathrm{H}$ NPs catalyst.

The stable silica gel nanoparticles are easily prepared [17] and used for preparation of catalyst $\left(\mathrm{SiO}_{2}-\mathrm{OSO}_{3} \mathrm{H} \mathrm{NPs}\right)$.

To optimize the reaction conditions, the reaction of benzaldehyde and 4-hydroxycoumarin was used as a model reaction. Initially, the catalytic activity of $\mathrm{SiO}_{2}-\mathrm{OSO}_{3} \mathrm{H} \mathrm{NPs}$ has been compared with other catalysts, according to the obtained data, and this catalyst afforded good yields; however, it has limitations of long reaction time, harsh reaction conditions, and often expensive catalysts (Table 1, entry 1-6). In order to determine the optimum quantity of $\mathrm{SiO}_{2}-\mathrm{OSO}_{3} \mathrm{H}$ NPs, model reaction was carried out at reflux in ethanol condition (Table 1, entry 7-9). $\mathrm{SiO}_{2}-\mathrm{OSO}_{3} \mathrm{H}$ NPs (0.003 g) gave an excellent yield in $20 \mathrm{~min}$ (Table 1 , entry 8 ). The previous reaction was also examined in various solvents. The best results were obtained when EtOH was used as a solvent at reflux (Table 1 , entry 8 ). An interesting feature of this method is that the reagent can be regenerated at the end of the reaction and can be used several times without losing its activity. To recover the catalyst, after completion of the reaction, the mixture was filtered, and catalyst was washed with $\mathrm{CHCl}_{3}$, and then the solid residue dries. This process was repeated for two cycles, and the yield of product $4 \mathbf{a}$ did not change significantly (Table 1, entry 12, 13). 
TABLE 1: Synthesis of $\mathbf{4 a}$ under various conditions.

\begin{tabular}{|c|c|c|c|c|c|}
\hline Entry & Catalyst (amount) & Cond./Sol. & Time (min) & Yield $^{\mathrm{a}}(\%)$ & Reference \\
\hline 1 & $\mathrm{I}_{2}(10 \mathrm{~mol} \%)$ & $100^{\circ} \mathrm{C} / \mathrm{H}_{2} \mathrm{O}$ & 25 & 97 & [6] \\
\hline 2 & $\mathrm{TBAB}^{\mathrm{b}}(4 \mathrm{~mol} \%)$ & $120^{\circ} \mathrm{C} /-$ & 20 & 85 & [7] \\
\hline 3 & [bmim]BF4 (4 mmol) & $60-70^{\circ} \mathrm{C} /-$ & 120 & 84 & [8] \\
\hline 4 & $\operatorname{SDS}^{\mathrm{c}}(0.2 \mathrm{~mol}, 57.6 \mathrm{mg})$ & $60^{\circ} \mathrm{C} / \mathrm{H}_{2} \mathrm{O}$ & 140 & 90 & [9] \\
\hline 5 & [PSebim][OTf] (0.5 mol\%) & $70^{\circ} \mathrm{C} /-$ & 120 & 95 & {$[10]$} \\
\hline 6 & {$\left[\mathrm{MIM}\left(\mathrm{CH}_{2}\right)_{4} \mathrm{SO}_{3} \mathrm{H}\right]\left[\mathrm{HSO}_{4}\right](3 \mathrm{~mol} \%)$} & $80^{\circ} \mathrm{C} /-$ & 30 & 92 & [11] \\
\hline 7 & $\mathrm{SiO}_{2}-\mathrm{OSO}_{3} \mathrm{H}$ NPs $(0.001 \mathrm{~g})$ & $80^{\circ} \mathrm{C} / \mathrm{EtOH}$ & 20 & 89 & - \\
\hline 8 & $\mathrm{SiO}_{2}-\mathrm{OSO}_{3} \mathrm{H}$ NPs $(0.003 \mathrm{~g})$ & $80^{\circ} \mathrm{C} / \mathrm{EtOH}$ & 20 & 93 & - \\
\hline 9 & $\mathrm{SiO}_{2}-\mathrm{OSO}_{3} \mathrm{H}$ NPs $(0.005 \mathrm{~g})$ & $80^{\circ} \mathrm{C} / \mathrm{EtOH}$ & 20 & 93 & - \\
\hline 10 & $\mathrm{SiO}_{2}-\mathrm{OSO}_{3} \mathrm{H}$ NPs $(0.003 \mathrm{~g})$ & $100^{\circ} \mathrm{C} / \mathrm{H}_{2} \mathrm{O}$ & 20 & 87 & - \\
\hline 11 & $\mathrm{SiO}_{2}-\mathrm{OSO}_{3} \mathrm{H}$ NPs $(0.003 \mathrm{~g})$ & $40^{\circ} \mathrm{C} / \mathrm{CH}_{2} \mathrm{Cl}_{2}$ & 20 & 82 & - \\
\hline 12 & $\mathrm{SiO}_{2}-\mathrm{OSO}_{3} \mathrm{H}$ NPs $(0.003 \mathrm{~g}), 2$ nd run & $80^{\circ} \mathrm{C} / \mathrm{EtOH}$ & 20 & 89 & - \\
\hline 13 & $\mathrm{SiO}_{2}-\mathrm{OSO}_{3} \mathrm{H}$ NPs $(0.003 \mathrm{~g}), 3 \mathrm{rd}$ run & $80^{\circ} \mathrm{C} / \mathrm{EtOH}$ & 20 & 87 & - \\
\hline
\end{tabular}

${ }^{\mathrm{a}}$ Isolated yield, ${ }^{\mathrm{b}}$ tetrabutylammonium bromide, and ${ }^{\mathrm{c}}$ sodium dodecyl sulfate.

TABLE 2: $\mathrm{SiO}_{2}-\mathrm{OSO}_{3} \mathrm{H}$ NPs catalyzed the synthesis of biscoumarin derivatives.

\begin{tabular}{|c|c|c|c|c|c|}
\hline \multirow{2}{*}{ Entry } & \multirow{2}{*}{$\mathrm{Ar}$} & \multirow{2}{*}{ Product } & \multirow{2}{*}{ Yield $^{\mathrm{a}} \%$} & \multicolumn{2}{|c|}{ m.p. $/{ }^{\circ} \mathrm{C}$} \\
\hline & & & & Found & Reported [Ref] \\
\hline 1 & $\mathrm{C}_{6} \mathrm{H}_{5}$ & $4 a$ & 93 & $228-230$ & $229-231[11]$ \\
\hline 2 & $4-\mathrm{BrC}_{6} \mathrm{H}_{4}$ & $4 b$ & 86 & $266-268$ & $265-267$ [9] \\
\hline 3 & $4-\mathrm{FC}_{6} \mathrm{H}_{4}$ & $4 c$ & 90 & $211-213$ & $213-215$ [9] \\
\hline 4 & $4-\mathrm{MeC}_{6} \mathrm{H}_{4}$ & $4 d$ & 96 & $268-270$ & $266-269$ [11] \\
\hline 5 & $2-\mathrm{OHC}_{6} \mathrm{H}_{4}$ & $4 e$ & 94 & $253-255$ & $254-256$ [11] \\
\hline 6 & $4-\mathrm{OHC}_{6} \mathrm{H}_{4}$ & $4 \mathrm{f}$ & 93 & 194-196 & $193[5]$ \\
\hline 7 & 4- $\left(\mathrm{CH}_{3}\right)_{2} \mathrm{NC}_{6} \mathrm{H}_{4}$ & $4 \mathrm{~g}$ & 92 & $221-223$ & $222-224[9]$ \\
\hline 8 & $3-\mathrm{NO}_{2} \mathrm{C}_{6} \mathrm{H}_{4}$ & $4 h$ & 95 & $215-217$ & $214-215[11]$ \\
\hline 9 & $4-\mathrm{NO}_{2} \mathrm{C}_{6} \mathrm{H}_{4}$ & $4 i$ & 96 & $233-235$ & $233-235$ [11] \\
\hline 10 & $3-\mathrm{ClC}_{6} \mathrm{H}_{4}$ & $4 j$ & 91 & $222-224$ & $221-223[11]$ \\
\hline 11 & $4-\mathrm{ClC}_{6} \mathrm{H}_{4}$ & $4 k$ & 95 & $262-264$ & $261-263[11]$ \\
\hline 12 & 3-Pyridyl & 41 & 88 & $279-281$ & $278[5]$ \\
\hline 13 & $3-\mathrm{NO}_{2}-4-\mathrm{ClC}_{6} \mathrm{H}_{3}$ & $4 \mathrm{~m}$ & 92 & $249-252$ & - \\
\hline 14 & $2,4-\mathrm{ClC}_{6} \mathrm{H}_{3}$ & $4 n$ & 89 & $198-200$ & - \\
\hline 15 & $4-\mathrm{NO}_{2} \mathrm{C}_{6} \mathrm{H}_{4} \mathrm{CO}$ & $5 a$ & 96 & $249-251$ & - \\
\hline 16 & $4-\mathrm{BrC}_{6} \mathrm{H}_{4} \mathrm{CO}$ & $5 b$ & 90 & 204-207 & - \\
\hline 17 & $\mathrm{C}_{6} \mathrm{H}_{5} \mathrm{CO}$ & $5 \mathrm{c}$ & 93 & 209-211 & - \\
\hline
\end{tabular}

${ }^{\mathrm{a}}$ Isolated yield.

To study the scope of the reaction, a series of aromatic aldehydes or phenylglyoxals and 4-hydroxycoumarin catalysed by $\mathrm{SiO}_{2}-\mathrm{OSO}_{3} \mathrm{H}$ NPs were examined (Scheme 1). The results are shown in Table 2 . In all cases, aromatic aldehyde or phenylglyoxals substituted with either electrondonating or electron-withdrawing groups underwent the reaction smoothly and gave products in excellent yields.

The compounds $4 \mathbf{a}-\mathbf{l}$ were characterised by their ${ }^{1} \mathrm{H}-$ NMR and IR spectroscopies and elemental analyses. Spectral data were compared with the literature data $[5,9,11]$.

Compounds $\mathbf{4 m}, \mathbf{n}$ and $\mathbf{5 a}-\mathbf{c}$ were new, and their structures were deduced by elemental and spectral analysis. The ${ }^{1} \mathrm{H}-\mathrm{NMR}$ spectrum of compound $\mathbf{5} \mathbf{a}$ exhibited proton of methine at $6.4 \mathrm{ppm}$, and $\mathrm{OH}$ proton is observed at $11.3 \mathrm{ppm}$ which disappears after addition of some $\mathrm{D}_{2} \mathrm{O}$ to the $\mathrm{CDCl}_{3}$ solution of 5a. There are observed multiplets between 7.34 and $8.29 \mathrm{ppm}$ which are related to aromatic protons. The ${ }^{13} \mathrm{C}-\mathrm{NMR}$ spectrum of compound $\mathbf{5 a}$ showed 15 signals in agreement with the proposed structure. The IR spectrum of compound 5a also supported the suggested structure.

\section{Conclusion}

In summary, we have reported an easy and efficient protocol for the synthesis of biscoumarins in the easily accessible $\mathrm{SiO}_{2}-$ $\mathrm{OSO}_{3} \mathrm{H}$ nanoparticles. The method offers marked improvement with its operational simplicity and short reaction time and affords excellent yield. The solid phase acidic catalyst was 
<smiles>O=c1cc(O)c2ccccc2o1</smiles>

1<smiles>O=c1cc(O)c2ccccc2o1</smiles>

1

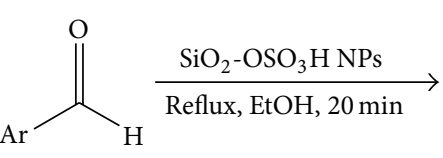<smiles>O=c1oc2ccccc2c(O)c1C([Al])c1c(O)c2ccccc2oc1=O</smiles>

2<smiles>O=C([Al])C(c1c(O)c2ccccc2oc1=O)c1c(O)c2ccccc2oc1=O</smiles>

$5 a-c$

SCHEme 1: Synthesis of biscoumarins by condensation of 4-hydroxycoumarin with an aromatic aldehyde or phenylglyoxals using $\mathrm{SiO}_{2}-\mathrm{OSO}_{3} \mathrm{H}$ NPs as catalyst.

reusable for a number of times without appreciable loss of activity. The present method does not involve any hazardous organic solvent. Therefore, this procedure could be classified as green chemistry.

\section{Acknowledgment}

The authors gratefully acknowledge the financial support from the Research Council of Islamic Azad University of Yazd.

\section{References}

[1] J. H. Lee, H. B. Bang, S. Y. Han, and J.-G. Jun, "An efficient synthesis of (+)-decursinol from umbelliferone," Tetrahedron Letters, vol. 48, no. 16, pp. 2889-2892, 2007.

[2] R. D. R. S. Manian, J. Jayashankaran, and R. Raghunathan, "A rapid access to indolo[2,1-a]pyrrolo $\left[4^{\prime}, 3^{\prime}: 4,5\right]$ pyrano $[5,6$ c]coumarin/[6,5-c]chromone derivatives by domino Knoevenagal intramolecular hetero Diels-Alder reactions," Tetrahedron Letters, vol. 48, no. 8, pp. 1385-1389, 2007.

[3] H. Zhao, N. Neamati, H. Hong et al., "Coumarin-based inhibitors of HIV integrase," Journal of Medicinal Chemistry, vol. 40, no. 2, pp. 242-249, 1997.

[4] I. Manolov, S. Raleva, P. Genova et al., "Antihuman immunodeficiency virus type 1 (HIV-1) activity of rare earth metal complexes of 4-hydroxycoumarins in cell culture," Bioinorganic Chemistry and Applications, vol. 2006, Article ID 71938, 7 pages, 2006.

[5] K. M. Khan, S. Iqbal, M. A. Lodhi et al., "Biscoumarin: new class of urease inhibitors; Economical synthesis and activity," Bioorganic and Medicinal Chemistry, vol. 12, no. 8, pp. 19631968, 2004.

[6] M. Kidwai, V. Bansal, P. Mothsra et al., "Molecular iodine: a versatile catalyst for the synthesis of bis(4-hydroxycoumarin) methanes in water," Journal of Molecular Catalysis A, vol. 268, no. 1-2, pp. 76-81, 2007.

[7] J. M. Khurana and S. Kumar, "Tetrabutylammonium bromide (TBAB): a neutral and efficient catalyst for the synthesis of biscoumarin and 3,4-dihydropyrano[c]chromene derivatives in water and solvent-free conditions," Tetrahedron Letters, vol. 50, no. 28, pp. 4125-4127, 2009.

[8] J. M. Khurana and S. Kumar, "Ionic liquid: an efficient and recyclable medium for the synthesis of octahydroquinazolinone and biscoumarin derivatives," Monatshefte fur Chemie, vol. 141, no. 5, pp. 561-564, 2010.

[9] H. Mehrabi and H. Abusaidi, "Synthesis of biscoumarin and 3,4dihydropyrano[c]chromene derivatives catalysed by sodium dodecyl sulfate (SDS) in neat water," Journal of the Iranian Chemical Society, vol. 7, no. 4, pp. 890-894, 2010.

[10] W. Li, Y. Wang, Z. Wang, L. Dai, and Y. Wang, "Novel $\mathrm{SO}_{3} \mathrm{H}$-functionalized ionic liquids based on benzimidazolium cation: efficient and recyclable catalysts for one-pot synthesis of biscoumarin derivatives," Catalysis Letters, vol. 141, no. 11, pp. 1651-1658, 2011.

[11] N. Tavakoli-Hoseini, M. M. Heravi, F. F. Bamoharram, A. Davoodnia, and M. Ghassemzadeh, "An unexpected tetracyclic product isolated during the synthesis of biscoumarins catalyzed by $\left[\mathrm{MIM}\left(\mathrm{CH}_{2}\right)_{4} \mathrm{SO}_{3} \mathrm{H}\right]\left[\mathrm{HSO}_{4}\right]$ : characterization and $\mathrm{X}$ ray crystal structure of 7-(2-hydroxy-4-oxo-4H-chromen-3-yl)$6 \mathrm{H}, 7 \mathrm{H}$-chromeno[4,3-b]chromen-6-one," Journal of Molecular Liquids, vol. 163, no. 3, pp. 122-127, 2011.

[12] B. Sadeghi, A. Hassanabadi, and S. Bidaki, "Synthesis of nanoparticles silica supported sulfuric acid $\left(\mathrm{NPs} \mathrm{SiO}_{2}-\mathrm{H}_{2} \mathrm{SO}_{4}\right)$ : a solid phase acidic catalyst for one-pot synthesis of $4 \mathrm{H}$ chromene derivatives," Journal of Chemical Research, vol. 35, no. 11, pp. 666-668, 2011.

[13] M. Khazaei, M. Anary-Abbasinejad, A. Hassanabadi, and B. Sadeghi, " $\mathrm{ZnO}$ nanoparticles: an efficient reagent, simple and one-pot procedure for synthesis of highly functionalized dihydropyridine derivatives," E-Journal of Chemistry, vol. 9, no. 2, pp. 615-620, 2012.

[14] B. Sadeghi, A. Namakkoubi, and A. Hassanabadi, " $\mathrm{BF}_{3} \cdot \mathrm{SiO}_{2}$ nanoparticles: a solid phase acidic catalyst for efficient onepot Hantzsch synthesis of 1,4-dihydropyridines," Journal of Chemical Research, vol. 37, pp. 11-13, 2013.

[15] B. Sadeghi, S. Zavar, and A. Hassanabadi, "Monolayer-protected silver nanoparticles: an efficient and versatile reagent for the synthesis of 3,4-dihydropyrimidine-2-(1H)-ones (thiones)," Journal of Chemical Research, vol. 36, pp. 343-346, 2012. 
[16] B. Sadeghi and M. Ghasemi Nejad, "Silica sulfuric acid: an ecofriendly and reusable catalyst for synthesis of benzimidazole derivatives," Journal of Chemistry, vol. 2013, Article ID 581465, 5 pages, 2013.

[17] K. Lee, A. N. Sathyagal, and A. V. McCormick, "A closer look at an aggregation model of the Stober process," Colloids and Surfaces A, vol. 144, no. 1-3, pp. 115-125, 1998. 

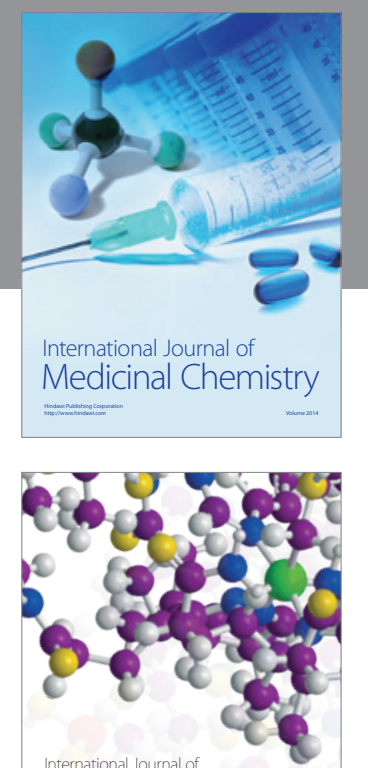

\section{Carbohydrate} Chemistry

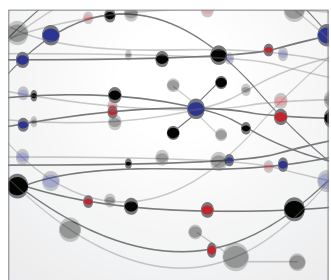

The Scientific World Journal
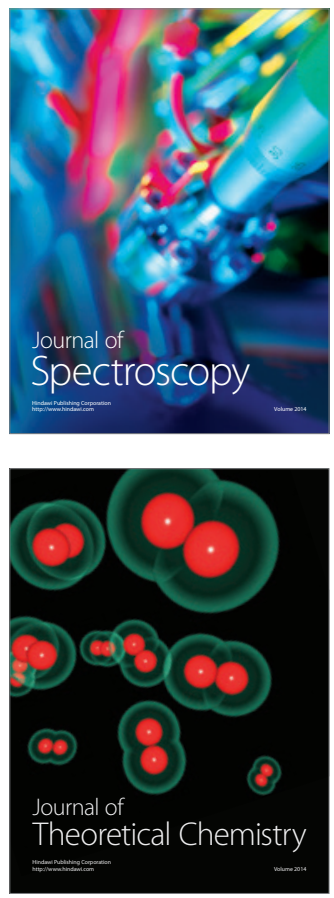
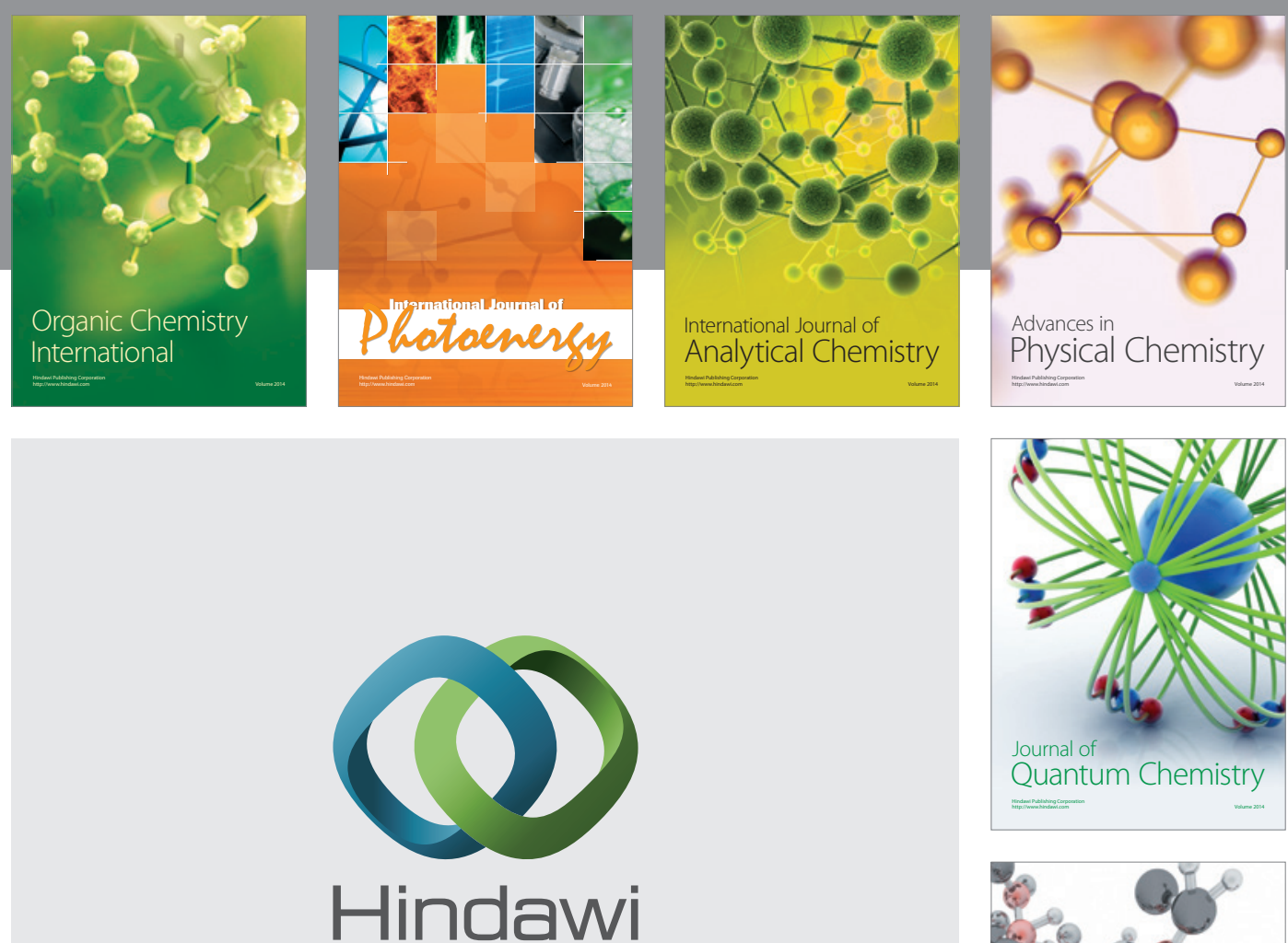

Submit your manuscripts at

http://www.hindawi.com

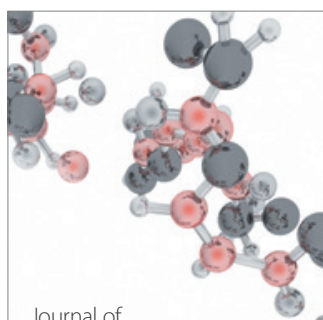

Analytical Methods

in Chemistry

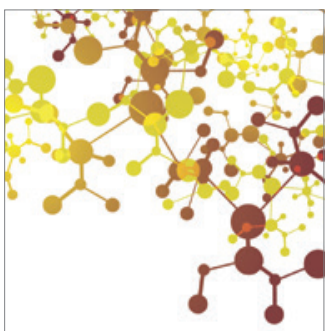

Journal of

Applied Chemistry

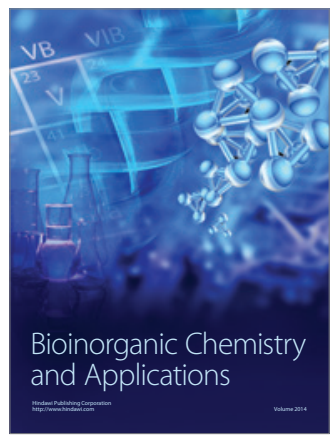

Inorganic Chemistry
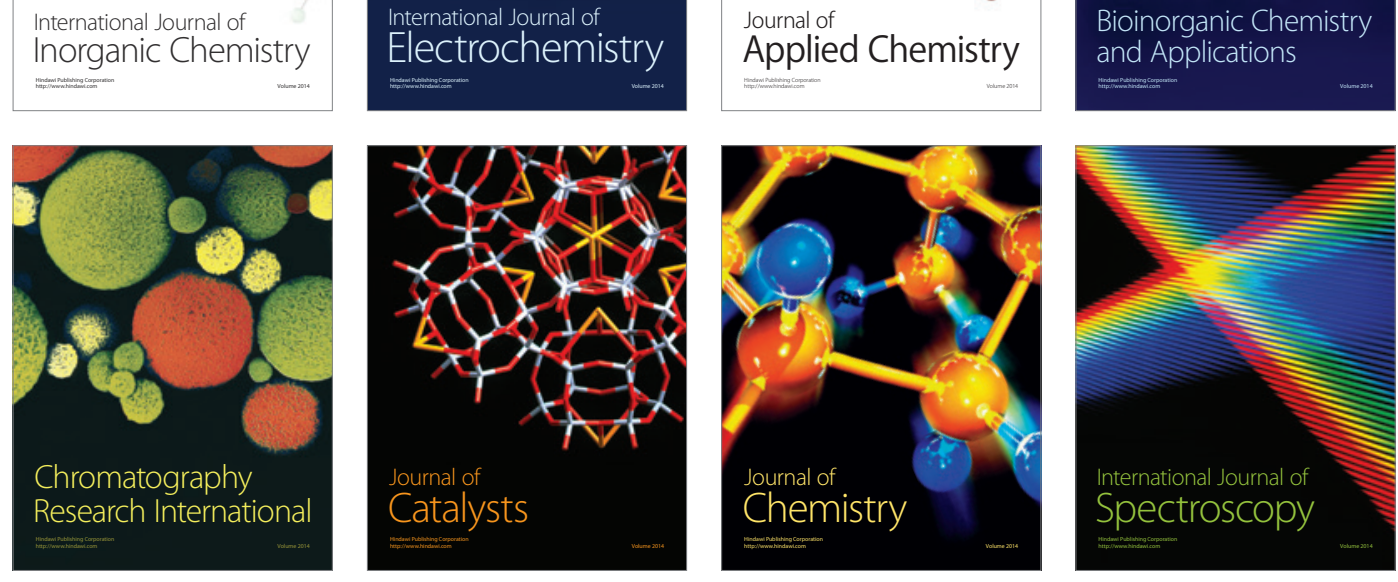